\title{
WILEY
}

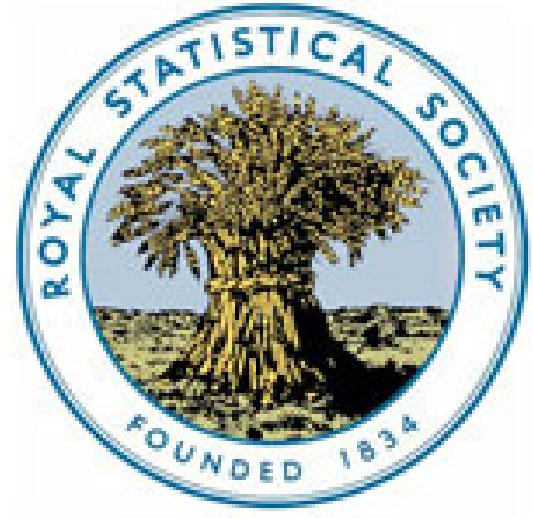

Opening Address of the President of the Department IV, "Economy and Trade," of the National Association for the Promotion of Social Science, at the Eighteenth Annual Congress, held at Glasgow, October, 1874

Author(s): George Campbell

Source: Journal of the Statistical Society of London, Vol. 37, No. 4 (Dec., 1874), pp. 489-505

Published by: Wiley for the Royal Statistical Society

Stable URL: http://www.jstor.org/stable/2338698

Accessed: 13/01/2015 23:59

Your use of the JSTOR archive indicates your acceptance of the Terms \& Conditions of Use, available at http://www.jstor.org/page/info/about/policies/terms.jsp

JSTOR is a not-for-profit service that helps scholars, researchers, and students discover, use, and build upon a wide range of content in a trusted digital archive. We use information technology and tools to increase productivity and facilitate new forms of scholarship. For more information about JSTOR, please contact support@jstor.org.

Wiley and Royal Statistical Society are collaborating with JSTOR to digitize, preserve and extend access to Journal of the Statistical Society of London. 


\section{Opening Address of the President of the Department IV, "Economy and Trade," of the National Association for the Promotion of Social Science, at the Eighteentrin Annual Congress, held at Glasgow, October, 1874. By Sir George CAMPBELL, D.C.L., K.C.S.I.}

I HAVE been so much and so actively engaged abroad, that I fear I am but ill qualified to speak of this great subject. I must confine myself to some general observations which occur to one, who from a distance has had what may be called a sort of bird's-eye view of events passing in Europe; and I think that you will view leniently my shortcomings and errors.

It seems to me that the pervading element in recent changes of opinion on economical questions, is a certain distrust of the orthodox doctrines of political economy, such as were at one time received-a recognition of considerable disturbances and wide deviations due to what I may call moral causes. It has come to be understood that in practice men do not always, or even generally, follow the strict paths of pecuniary self-interest, and that in dealing with human affairs we must make large allowances for certain attractions not originally taken into account in the science of political economy. In fact, pure political economy has been to a great extent supplemented by what may be called mixed political economy.

I would class the disturbing causes under the heads of, first, habit and custom; second, ignorance and prejudice; and third, the fact long preached, but little accepted in modern days, that wealth and happiness are not always commensurate; since it may be that a smaller total of wealth distributed in one way, or under certain conditions may afford more happiness, and consequently be more sought after, than a greater total of wealth distributed or accumulated in another way. I think we can have no true economical science without recognising that the result depends quite as much on the distribution of wealth, as on its actual amount. The fact seems to be that in primitive times, before wealth was so great and before economy had been reduced to a science, the wisdom of our ancestors recognised and acted on many of the considerations which, in later days, we have overlooked; and along with much gross error and prejudice they had some elements of social wellbeing and happiness, which have been comparatively wanting in modern times. Hence arises a sort of radical reaction-a disposi- 
tion on the part of some of the most advanced reformers in some things to revert to earlier phases of society, when wealth in the hands of individuals was less exclusively king; when castes and classes were less widely separated; and when institutions prevailed, which admitted greater numbers to the privileges and enjoyment of property or of common rights.

Taking in the order in which $I$ have stated them the classes of causes most likely to disturb the rules of pure political economy, I will not here say much on habit and custom, though in truth custom is of enormous importance and greatly influences most affairs. It is abundantly evident that these things do very largely affect human action, even in the most civilised countries; and no man can be a true statesman, who makes his calculations without allowing for their effect. So long as human nature is human nature, men and still more women, will be influenced by habit and custom.

Mere ignorance is perhaps scarcely so important, inasmuch as while the influence of habit is perpetual, ignorance is an ice-bound form which melts and disappears under the influence of the sun of knowledge, which in these days is melting with great rapidity, and which modern advances seem likely very rapidly to reduce to a minimum.

The grand difficulty in establishing a free and good social state in these days seems to me to consist in this, that up to this time almost all, if not all, the examples of successful free States are States in which real freedom has been confined to a body of freemen-a very large body, even a majority of the populations, it may be, but still an exclusive body, not comprising the whole population. The menial and inferior duties have always been performed by a helot population-either actual slaves, serfs of the soil, or persons nominally free, but really by gross ignorance kept down to a quasihelot position. The old republics of Greece and Rome had large bodies of slaves; so had the American Republic till the other day. in the middle ages, the free nations of Europe seem always to have dominated over subject races of serfs. On the Continent many of the people had not fully emerged from that state till modern days. In Eingland, till quite the other day, the agricultural labourer was a rude and ignorant serf, debarred by ignorance from any effort to improve his condition. Even in educated Scotland we are told, that in comparatively recent times miners were almost or quite slaves; and $I$ believe $I$ am right in saying that in modern times, in this manufacturing West, the lower kinds of labour in the great industrial establishments are for the most part not done by Scotchmen, but by strangers imported to fill the gap left by the want of ignorance in Scotland.

Even in Scotland we now know that a good deal of ignorance 
has remained. But in Scotland, England, and Ireland too, measures are taken which will render the people no longer ignorant, and we must make up our minds for the changes necessarily resulting. Not only education proper, but those great educators, railways and steamships and the press, are rapidly bringing things to that point that ignorance will no longer render easy, bargains for the performance of inferior toil.

When the ignorance which maintains a pariah caste is dissipated, we come to that state of things which already to a great extent exists in America: among equals no one will submit to do the inferior work, except for very high pay. Hence a social revolution, which we are now going through. It may be doubted whether the effect will be to raise the comparative position of the aristocrats of manual labour, the skilled mechanics; but we certainly witness a process which must be lasting, viz., the comparative elevation of the wages and positions of the labourers who perform the more disagreeable and inferior labours.

This seems to me to be one of the causes of recent changes and rise of wages. Another is, no doubt, the increased facilities of emigration, the consequent drain to America, and the tendency to an equalisation of the conditions of the labourer in Europe and America.

How far, then, is the change to go? Is there a limit to it, or are wages to go on rising indefinitely? I think those who are too sanguine in their anticipations of continued improvement in the position of the labourer, must remember several drawbacks. Every great rise in the price of production mast tend to check that great development of our manufactures and trade, which has hitherto more than kept pace with the population. Under improved conditions of life we may expect that population will continue to increase very rapidly. And there seems much reason to believe that the flow into America has already gone far to reduce the difference of level which has hitherto produced so strong a labour-current to the West.

But, beyond these considerations, which most of you understand better than I can do, there is another to which I would particularly ask your attention, and in regard to which I can speak with more personal knowledge. These countries of Western Europe are not the only or the chief labour-markets of the world. On the contrary, in Southern and Eastern Asia we have a population infinitely more numerous, and where wages are out of all comparison cheaper. It may be that the same influences which tend to spread populations and equalise wages as between Europe and America, may soon tend to produce the same effects as between Asia and the countries where labour is now dear. Already Chinese labour has VOL. XXXVII. PART IV. 
come into competition with white labour, and it has become evident that the Chinese are no mean competitors.

In truth the same causes-prejudice and ignorance and want of means of communication-which have hitherto kept in degradation much of the populations of Europe, have also kept cooped up in their own country, at humble labour on low wages, the great Eastern populations. Wherever there is peace these populations increase; and if the bonds which have restrained them are relaxed, they may greatly affect the labour markets of the world.

The Chinese have a physique very little inferior to Europeans, and they have an industry and perseverance superior to many Europeans. They have hitherto been much restrained by political circumstances and social bonds; otherwise they are singularly free from any trammels of ignorance and prejudice. I have often been inclined to think that if the gates of China were fairly opened it would be a question whether the New Worlds are to belong to the Americans or to the Chinese. The success of the Chinese as colonists is mainly retarded by one social prejudice-they do not like to take their women abroad. But, I believe there are symptoms that this may be overcome, and, if so, I do not see what there is to prevent the Chinese from multiplying and replenishing the earth.

Then we come to the vast populations of our great Indian territories. Recent events have created a painful interest in the density and the rapid increase of these populations. More and more this country seems to feel that, having undertaken their government, it is our duty to do what we can to facilitate their employment in a way which may mitigate the evils resulting from overcrowding, uniformity of labour, and lowness of living. There are still large parts of India in which the wages of a labouring man are not more than $2 \frac{1}{2} d$. per diem, and $3 d$. is an outside wage in all the rural parts. Whether we facilitate a change or not, the world is progressing, and there is some probability that many of these people may come into the labour market of the world. In their case pre-eminently, it is prejudice and ignorance which have kept them back. Caste prejudices are being weakened. We are doing much to educate the people in India. Unheard-of facilities of locomotion are there provided. In several parts of the country the people are becoming accustomed to emigration. There seems no reason why at least our warmer colonies and possessions, should not be fully colonized by an Indian population. And it may be that even in our own country, if our own populations are elevated to occupations requiring energy and force, some of the inferior occupations may be taken by our Indian subjects. For instance, I think that in these days domestic service is not the work of European men. As things stand I would give that over entirely to women; 
and, if the women are too much for us, I believe that Indian servants, educated in this country to our habits and our energies, would do that duty excellently.

These Indians, though sprung in the main from the same original stock as ourselves, are now undoubtedly inferior in physique; but their intellect is good, and their manual skill great, and the experience of individuals proves that they are quite capable of thriving and improving in this country.

Emigration, moreover, apart, much attention has lately been drawn to the fact that in their own country, Indian labour in manufactories threatens a very dangerous competition with the manufacturing labour of this country. There is no concealing the fact that, inferior though they be in force and energy, the natives of India are just as well fitted as the people of this country for the kinds of work which are connected with machines. I have specially inquired on this point, and am told by those who have practical experience of the great mills recently established in India, that the natives do the work on which they are employed (that is, the manual labour) just as well as Dundee or Manchester hands. They have a distinct aptitude for this kind of thing; and I have never seen a pleasanter sight or a greater improvement in condition than is exhibited by large numbers of native men, women, and children employed in some of these mills. As yet, both in the jute mills of Calcutta and the cotton mills of Bombay, only the coarser fabrics have been attempted; but considering how recent this industry is, it may well be that great advances may soon be made. In some respects Indian mills labour under a disadvantage: coal is dear or inferior, European superintendence expensive, machinery must be obtained from a distance. Still the tendency must be to diminish these difficulties as mills become more numerous, and Indian minerals are more developed. I have no doubt many here can calculate pretty exactly what proportion to the whole cost of manufacture is represented by the cost of manual labour. It is certain that this labour is very much cheaper in India; and weighing that against the advantages on the other side, some opinion may be formed of the probable success of Indian manufactures. So far it is certain that they have given ground for sanguine expectations, and that consequently large additions are being made to the existing manufactories. A question has been propounded to you: "What are the probable effects of "the spread of manufacturing industry in Europe on the future " commercial properity of the United Kingdom?" And I beg to impress on you that the question must be extended to India, and that you must consider the possible effect of the spread of manufacturing industry in India. You are probably aware that at this moment the jute mills in and about Calcutta are being largely 
extended, the existing mills having been found remunerative in a very high degree. Some cotton mills are also started there, while at Bombay a great increase is taking place in the large cotton mills already existing, and cotton mills are started at several places in the interior.

This train of thought leads me to another of the special questions which will be propounded to you: "What are the best means " of drawing together the interests of the United Kingdom, India, "and the Colonies?" I think that in discussing this very wide question a great distinction must be drawn between the selfgoverned colonies on the one hand, and India, with other nativeinhabited and crown-governed colonies, on the other. In the latter we must do what we deem best in the interest of the colony or dependency, and that of the empire at large. But in the case of self-governed colonies it seems now to be accepted that freedom must prevail over the economical views which we may consider right; that they must do as they like, and that we must trust to the taste for British beer, British manufactures, and British mercantile connections, which British colonists carry with them, for any direct benefit to repay the money expended on these children of the mother country. My own view, subject to what I may hear at this meeting, is that self-government should not be conceded too early; and that there is no reason why a handful of first colonists should dispose of great countries, to the prejudice of those who come after them; and that the natives, if there be natives, must be fairly protected. But when a colony of British blood has become populous and settled, and self-government is conceded to it, I think that any attempt to maintain too close a connection with the mother country only leads to evil and bad feeling. All over the world I believe experience shows that highly centralised free governments do not succeed on a large scale-freedom is only possible on a large scale under a federal system, closer or loose as the constituent parts are near and similar, or the contrary. But be this as it may, I am firmly convinced that the British genius is not centralising, but of an intensely local and decentralising character. I observe that the moment a man born and bred in these isles settles in a colony or a dependency he ceases to put first the feelings of an Englishman or the interests of the empire-he becomes intensely local in all his views and interests-he is always ready to decry the interests of the mother country as opposed to the local interests which he has espoused-he is very touchy and difficult to deal with. For this reason especially, I greatly distrust all plans for imperial assemblies to represent the whole empire, and every scheme of that kind. I believe that it must come, and is coming to this-that when selfgovernment has been once conceded the interference of the British 
Parliament must almost cease, and we must be content to maintain as long as conveniently may be a loose political connection through the Crown or head of the State. The head of the State would then act as arbiter, and exercise an influence sufficient, it may be hoped, to settle disputed questions and maintain concord for a generation or two. But colonies are like chilaren; and when an elder child, such as Canada, has grown to maturity on another continent, has its own politics, connections, and complications there, and is practically out of our hand, I would certainly let it go free without more delay, and would relieve this country of the many embarrassments to which the connection may give rise. We may hope for long years of friendly intercourse with free colonies and colonies emancipated into free countries, if we only follow a negative policy, and keep clear of causes of offence. Canada I believe to be, under present arrangements, a burden and a risk to us. The Australian Colonies are differently situated, and a direct connection with them may no doubt be advantageously maintained for the present.

One of the best means of uniting the mother country with the colonies is no doubt the extension of telegraphic communication, and it is to be hoped that this will be gradually perfected. Especially in all directions we must hope to obtain cheaper telegraphic rates than those now charged by monopolist private companies. The rates on the ocean telegraphs are almost prohibitory to private correspondence.

In regard to India, the character of our connection is very different from that of the free colonies. Possibly we may some day fit that country for freedom, but the time has not yet come, nor approaches, when we can carry political freedom there beyond small local municipalities. The best, then, that we can do, whether for the interests of the United Kingdom or of India, to unite the two, is to govern India absolutely with wisdom and justice. Above all things we must give the greatest possible facilities to promote the flow of those things in which each country abounds to the other. Though I am old-fashioned enough to believe that even the rule of free trade has its exceptions, though I have thought that when actual famine of a severe type is on a country, its rulers may fairly retain its own food supplies, I heartily acknowledge that, as a rule, the freest exchange of commodities is incomparably the best system, and that the first duty of a ruler is to promote that exchange by liberal tariffs and liberal laws-by improved harbours, roads, and railways -by easy markets and other mercantile facilities, and by the industrial education and enlightenment of the people.

Now, we know that India is rich in a great, an industrious, an intelligent, and an orderly population, and in a vast extent of rich soil, made fertile by a tropical sun and almost tropical rains; but she wants capital and science, and energetic directors of labour. All 
these last the United Kingdom can above all other countries supply, and above all other countries the United Kingdom can take and use and improve the great products which the soil and populations of India supply. It must be, then, that two countries, each of which is as it were the converse and complement of the other, must, when brought into so close relation as are India and this country, benefit one another. The interests of both are the same; the measures that will promote the interests of the one will promote the interests of the other. The task of the Government is but to study the common interests, to remove obstructions, to maintain peace and quiet, and to let things find their natural level.

This country is full of capital. Much of that capital must and does find its way to India. Yet it is often said that capital does not go so freely to India as to some other countries. I believe that the way to an influx of British capital into India is more and more opened every day. But to secure the most abundant flow possible I think we want-

A better definition of the rights in land.

Improved judicial institutions.

An improvement in the English commercial law, better calculated to secure honesty on the part of agents and directors.

Improved facilities for the resort of Europeans to the better hill climates of India, facilities for their settling there, and facilities for the education of their children.

An improved social intercourse between Europeans and natives.

I find that perhaps the greatest difficulty we have now to deal with in European industrial enterprise in India is that too great haste to be rich, which leads men to be constantly seeking short cuts by speculation, rather than to settle down and slowly build up fortunes founded on the goodwill and co-operation of the natives, as the old race of settlers did. The greyheaded old planter, wielding an immense personal influence over the natives around him, is now very rare. Our nation has been demoralised by prosperity and speculation; tea industries and other industries have received rude shocks, and been much retarded, because many men have made teagardens and set up other enterprises, not to make tea or anything else, but to sell. In most industries we have now a healthier state of things, but still there is too much of a feverish expectation to make a rapid fortune in a few years as soon as a first success is achieved. I think that to secure steady and sure success planters and settlers must make up their minds to spend the best part of their lives in the country, as government servants do, to learn the languages, to conciliate the natives, and to make for themselves a place in the country. Certainly the most successful men in the long run are always those who get on best with the natives. 
I have not mentioned public works and improved communications as one of the improvements required in our Indian system, because I feel that we are already sufficiently alive to the need of these things, and are already doing as much as can reasonably be expected. On the other hand, I think there is extreme need of caution lest we should go too far in a right direction, and too much embarrass our finances by unprofitable works. In respect of improved communications we can hardly do too much, and much has been done. The railways already made in India are on the whole a great success; the trunk lines carry a very large traffic; and though very expensively built, pay quite as well as could be expected. The greatest railway of all, the East Indian, is already a paying line, and so is the Eastern Bengal. If we can sncceed in making cheap light railways as feeders to the main lines-so cheap that they will pay tolerably well-we shall have an excellent railway system in India. Already some such cheap lines have succeeded; and if in the future we lay them down judiciously, and avoid a too broad gauge on the one hand, and a pedantically narrow gauge on the other, we may well succeed with such works on a large scale. The difficulties in the way of large and substantial metalled roads in the plains of India are enormousthey are most expensive to make, and most expensive to maintain; it is therefore that I so much look to light railways.

In connection with this subject it may be mentioned that there is very widely spread in India enormons quantities of excellent iron ore. The coal is not so good, but it is tolerable, and in some parts there are great quantities of it close to the iron. If iron should become excessively dear in this country, a successful iron manufacture on a large scale will probably spring up in India. I understand that even now projects of this kind are on foot in a part of the country where there seems to be very great promise of success.

Railways cannot go to every village : we must have local roads of some kind, and the Indian Government certainly does not neglect this subject. There is generally a system of local taxation for roads; and of late in Bengal, where the permanent settlement was by many supposed to cause difficulty, a system of local rating for roads has been carried through, and put in practice with unexpected success.

There is, then, no laxity in providing India with sufficient means of communication. In respect also of accommodation for shipping, much has been and is being done. I am sure those of my mercantile friends who are connected with Calcutta will acknowledge that there at least we have lately given them modern appliances and facilities of the best description, and suited to the great steam traffic by the Suez Canal, which is every day developing, and which will more develop, if only care is taken that the ships are properly navigated. In almost every one of the many cases in which fine steamers have 
been lost on this route of late, the result has been due to no storms or other natural misfortunes, but simply to gross blunders of navigation. Surely these may be avoided.

You are well aware that great efforts are made to increase the productive power of India and secure the country against famine by means of irrigation. I trust and believe that much may still be done in this way. But the misfortune is that on Indian subjects public opinion in this country is apt to rush to extremes. It seemed at one time to be supposed that irrigation of any kind and at any cost must be the panacea for everything. In truth there are two sides to this irrigation question, and questions of extreme difficulty are involved, which can only be worked out with extreme care and patience. I earnestly trust that the new Minister of Public Works in India will be a careful and a patient man, who will go thoroughly into these questions and work them out thoroughly.

By other means also the productive resources of India may no doubt be increased. But here also we must not rush to too hasty conclusions. The natives of India, knowing their soil and climate, cultivate with a considerable skill and success, which we certainly cannot improve by rude and hasty means. To improve Indian agriculture and Indian staples we must give to the subject the atmost care, study, and practical application. I think that we ought to have a far better knowledge of the products and agriculture of India than we now have, and I trùst that steps are being taken to obtain this. We are attempting to commence schools of practical botany and agricultural chemistry; we hope to have an industrial survey of the whole country. I hope and believe that the result will be in the end a greater supply of the products most wanted in this country, and increased prosperity to India.

I have mentioned improved facilities for settlement and education in the better hill climates of India as one of the desiderata. I have doubts whether we can ever do justice to India till we have some sort of colonisation there under circumstances in which the race will not deteriorate. We want a class who may become a sort of medium between ourselves and the natives, and bring the two races closer together, instead of letting them drift farther apart, as is now, I think, the case. I have alluded to the decay of the old race of planters and settlers, and the substitution of young men too sanguine of becoming rapidly rich and going off again. Even among the servants of Government a good deal of the same feeling has resulted from change of system and increased facilities of communication with Europe. I want to tempt some Europeans to make India more completely their home, and to bring up children who may combine with European habits of thought and feeling a thorough knowledge of the natives and of native languages. I want a class of Europeans 
who understand the soil, the agriculture, and the products of the East, and who, with a European education, may be able to improve them. I also especially wish to develop among the better and highlyeducated classes of natives a physical robustness and a taste for practical arts, which may enable them to do for their own country what energetic and educated men have done in Europe. I trust that we have made a beginning in this direction, and that good fruit will soon come of a friendly and efficient working together of European and native energy.

I have not yet touched on the third of the causes of variation from the strict rules of pure political economy which I stated, viz., the possibility of greater happiness resulting from an advantageons distribution of wealth as distinguished from its gross amount. It is generally, I think, deemed to be a source of weakness and social evil in this country that there is a tendency more and more to accumulate wealth in few hands, and to divide the population into a few who have very much, and the many who have nothing. I am myself inclined to think that we too much tend to substitute a platocracy for the aristocratic rule, which has in great degree ceased. Be this as it may, I think there can be no doubt that a great source of weakness in this country, as compared to some other countries, one which may give them the advantage in the long run, is the want of saving accumulation and property among the labouring population of England, and I fear I must say of Scotland also. We now know that, if the large capital of France is not so large as ours, the amount of wealth in France in the hands of petty holders is enormous. In other European countries, also, the people are, I believe, saving in their habits. Even in Ireland we know that the petty cottier tenants save money to buy farms, and give their daughters portions in a way which, I fear, is very rare among British labourers. Why is this ? The Scotch, at any rate, are by nature a prudent race. Why do Scotchmen earning good wages in our manufactories not save like Frenchmen or Irishmen, and buy fields and houses and stocks and shares? I imagine that in Scotland we have now become involved in the English system, and that the English system is not favourable to saving. Englishmen and most Scotchmen have been too long divorced from the responsibilities of property and of complete selfdependence. I take it that the more people cease to work for themselves and become labourers for others, the less the necessities and forethought which beget prudence influence them. When a man cultivates a bit of land on his own account, or carries on any trade on his own account, he must look to the vicissitudes of season and the market. He cannot live from hand to mouth from day to day or from week to week. He must have either money by him or credit to enable him to tide over a rainy day, a bad harvest, or a bad 
market. The necessity of the case forces him. to be prudent and forecasting, and a man so situated generally is so.

On the other hand, the man who receives a weekly wage is too apt to spend it and to trust for the next week to the wages of the next. I believe that in other countries also, as the system extends under which the mass of the workmen are labourers without responsibilities, so also prudence diminishes; and I apprehend that by far the greatest question of modern days is, how to reconcile a great manufacturing system with prudence-how to give the workman a sufficient interest in the produce of their labour, a sufficient incentive to exertion, and a sufficient motive to prudence. I do believe that for many reasons $\mathrm{I}, 000 \mathrm{l}$. saved by ten workmen is more valuable to the country than 2,000l. saved by a capitalist, and that a thousand houses and gardens owned by labourers contribute far more to the safety to the country, to the security of property, and to a wholesome social state, than one great estate owned by one man. There is, after all, no conservative force so great as the possession of property by a large proportion of the people. It is the old story of a broad basis instead of a body balanced on its apex. However large the increase of wealth accumulated in masses, however much the workmen may have to spend, no system can be safe or prudent which does not in practice promote economy and prudence among the labouring classes.

In this respect I believe that the British labourer lies under a special and peculiar disadvantage. Men are seldom prudent in the abstract; they must have before them some visible, tangible, and highly-prized reward for which they strive. In countries where the land is much subdivided, where petty holdings and houses and gardens, such as the labourer can hold and enjoy, are very numerous and always in the market, the labourer strives for the possession of such things. The French or the Belgian peasant or labourer longs to become a proprietor, the Irishman to acquire the tenant-right of a small farm. In countries where the public loans and the shares in joint-stock enterprises are arranged to attract petty holders, petty people are found to take them. But, under our English system, the land is daily more and more massed by the very richcomparatively little that is successful has been done to make it accessible to the poor. Our public loans and our enterprises are managed by capitalists and financiers; the poor have little temptation to engage in joint-stock enterprises, and our commercial laws give them little security that they will be fairly and honestly treated if they do. Certain it is that the more wages are received the more is spent, the more the revenue derived from spirits and such things increases. There is not at present sufficient inducement to prudence and saving. 
I believe, then, that our future more than on anything else depends on the solution of the most difficult problem, the reconciling of labour, for or under the guidance of capitalists, with pradence on the part of the labourer. We must, if possible, so arrange our land laws that garden-plots in convenient situations may be easily available to the industrious mechanic. We must so arrange our associated labour that the industrious and energetic man may earn in proportion to his industry and energy. We must so regulate the laws under which money is invested in industrial enterprise, that the small holder may be secure of fair treatment and have fair expectations of a good return. In one shape or another, if' this nation is to hold its own, we must give sufficient facilities for and inducements to prudence and saving.

These are heary and difficult tasks. Success will only be achieved after many attempts, and probably many failures. And here I must avow my belief that the Imperial Parliament, as it is now constituted, is not capable of efficiently dealing with the many social problems which present themselves, and of effecting the many reforms which we require. I have already said that I believe a highly centralised system in a great State is not compatible with freedom. Every day it becomes more and more apparent that our parliament is far too large and unwieldy a machine to deal with all the requirements of modern society. When great measures and great experiments are necessary we find its time frittered away on small measures and local measures, Mr. Gladstone's ministry was at any rate one of energy and action-politicians of one school say too much energy; but all the vigour of its youth and the strength of its majorities were spent on measures wholly local to Ireland, while England and Scotland were comparatively neglected. By the time that the attention of that ministry was turned to Britain, its forces were in a great degree exhausted. Another ministry has come into power, with a great majority, but the result of the session has shown how little can be done. The machine is too large and too cumbrous. Believing, then, that the social reforms which we require must necessitate many experiments in many directions; that to effect them we must enlist local experience, local energies, and local interests; that one parliament cannot do this, but that localised institutions may do it, I am so far a Home-ruler that I should like to see a large portion of our self-government transferred to local assemblies. In this respect, at any rate, I would in a great degree imitate the American system. I think that very much of the management of Irish affairs might be transferred to an Irish House of Representatives, or probably rather to two separate assemblies, representing two Irish provinces, north and south. I think that a very large portion of our Scotch affairs might be 
much better managed in a Scotch assembly. It may be that England might advantageously be split up into provinces. I feel confident that such provincial assemblies might do great good, and that very ample work would still be left for an Imperial Parliament.

Not only might many social reforms receive in local assemblies that attention and elaboration which they cannot have in a great parliament of the nation, but also I think that there would be very great advantage in the variety of local experiments which might be tried in different parts of the country, and under various conditions. One province would profit by the experience, the successes, and the failures of another; a healthy competition would be excited, and out of various trials progress, real and substantial, might be achieved. The difficulties in our way are so great that they will never be overcome without the concurrent efforts of many minds, and as the issue of many trials. Such efforts and such trials might, I think, be obtained under a sort of federal and provincial system of government. I do not think that they will be adequately obtained under the present system.

I have alluded to what seems to me the need of reform of the commercial law as regards the responsibilities of directors and agents and all those who are entrasted with other people's money. In my view, the English system in all things gives too much liberty to the individual, even to defrauding his neighbour, and too little protection to the community. It is surely a very unwholesome sign that all the great commercial frauds of recent years have gone uupunished, be it from the defect of the law, be it from the want of an efficient public prosecutor. Even I fear that the great and rich swindler often carries with him too much public sympathy. The poor man who steals or cheats to the value of sixpence, is sent to prison without sympathy and without mercy. Even the small debtor may still, I believe, be sent to prison. But the great financier, who has defrauded thousands of necessitous people of millions, is never convicted-he cannot be imprisoned for debt; he is speedily and effectually whitewashed, and begins a fresh career. I cannot think that associated undertakings can have a fair field till the law is strong enough to secure honesty in their management. In this, as in some other things, we must see that our system does not favour the rich.

In one respect most especially, protection to the public seems to be very much required. I mean in respect of those institutions which are designed to facilitate the economies and savings of the people-insurance offices, friendly societies, and the like. The receipts are immediate, the benefits are deferred, and nowhere is there such scope for fraudalent or impradent management. In 
truth, in nothing has there been such fraud or recklessness. We have had eminent judges in several cases denouncing these frauds from the bench, bat nothing has come of it-the perpetrators of the frauds have not been brought to justice. Constantly we see in the daily papers reports of most fraudulent cases which excite the indignation of the Lord Mayor and other right-minded magistrates before whom they come; but, somehow or other, whenever the thing looks ugly the matter is patched up, and the accused go free. I do submit that both more stringent laws and a better procedure for dealing with these cases are necessary.

One of the questions which has been specially submitted to you is, "What legislation should follow on the report of the Commission " on Friendly Societies?" Of the details of that subject I am not qualified to say much, but on the general subject of insurance I will venture to express my opinion that, seeing the enormous importance to the community of the machinery by which providence is promoted and rendered effectual, and the peculiar difficulties and risks which attend institutions to secure deferred benefits, when left in private hands, the Government should take a part much more active and effectual than any Government has yet proposed to undertake. In truth, I incline to the view, that much of the business of insurance should be undertaken by the State directly.

Local government and local taxation are subjects to which great attention has been paid by this Society, and my remarks on the necessity of decentralisation will show you that I, for one, attach to these subjects the most extreme importance. It has always been a main object of all my work in India to make a beginning among the natives of self-government, by enabling them to do for themselves, by the aid of local institutions, many things which it is impossible that a great Government should do for them. And in this country, also, I believe that the genius of our people and the ancient character of our institutions point in the same direction. Of late no doubt much has been done in the way of new forms of self-government, but I believe that there is still a want of system, a want of a proper demarcation of boundaries for local purposes, and a general want of method, which renders local government far from effective. We must consolidate our various forms of local government into one systematic whole.

Happily, it cannot be said, that as a people we now labour under an excessive taxation. A great reform has been wrought in that direction. But I may mention, as an ever present subject of discussion in a society such as this-the incidence of taxation-how far it falls fairly on different classes, how far the great masses of accumulated wealth, which most stand in need of protection, fairly pay for that protection; how far the cost of wars and a magnificent 
external policy is laid on those whose influence and whose organs create wars, so as to act as a deterrent from such courses. It is my impression that if every war were fairly paid for at the time by an increased income-tax, we should be sometimes much less inclined to adopt an unfriendly tone on very slight provocation.

And in my opinion perhaps the most important financial question of all in these days is, how far are nations or governments justified in throwing on posterity expenses incurred by themselves? Happily in this country we have not of late done much in this way, but the question is a very pressing one in India; and, as lenders, we in this country are enormously interested in the question whether all the bankrupt governments in the world can really charge their extravagances on their successors. Among the blessings of civilisation which we have communicated to Christians, Turks, Pagans, and infidels of all sorts, there is none which in these modern days they have so much appreciated as the system of State loans. To rotten governments nothing is more delightful. There is the double advantage that a loan both gives them an ample supply of money for their present necessities, and also builds up a strong interest bound to keep them on their legs. In India, to secure fidelity, native States keep their soldiers three years in arrear of pay; and so, if the King of the Cannibal Islands can raise some twenty millions on the London Stock Exchange-he cares not on what terms-he feels pretty secure that he cannot he overthrown so long as the financial powers of London can keep him up. In truth, this country is largely responsible for the extravagances of the world; and the question arises whether this may not be carried too far, and whether we may not some day awake to grand repudiations, by a generation which may with some show of reason say that they neither borrowed nor benefited by the money.

One or two more great subjects I shall barely mention.

Irish tenant-right is now being carried out in practice, but the whole broad question of tenant-right, or compensation for improvements in England and Scotland, is waiting for that practical discussion and solution, for which it is beginning to press.

Then there is that very difficult but most important subject, the game laws, which many have attempted to deal with, but no one has yet in any degree disposed of. Assuredly a solution of this question must be found.

The whole subject of female industrial employment is yet an open one. I for one believe that nothing could be worse, either for women or for the community in general, than that women should play the part of men, or obtain any sort of equality in the rights which have in all ages belonged to men. But there can be no sadder sight than to see women without adequate employment, and 
there are many branches of most useful industry which may, I think, be mainly given up to them.

Many other subjects might be mentioned, but I have said enough for the present.

I will only add that, for this subject of economy and trade, this great city of Glasgow where we are appears to offer greater opportunities for useful discussion than perhaps any other place in the kingdom. I will not offend the susceptibilities of our southern and western neighbours by calling it the second city in the empire-but this I may say, that while it is at least equal to any other, it far surpasses any other great city in the variety of its industries and its enterprises. There is scarcely an important branch of trade and commerce in which Glasgow does not participate; its citizens are shrewd and pushing to a degree which is nowhere surpassed, and in every quarter of the globe Glasgow men and Glasgow interests are largely represented. I feel that in such a place, I very unworthily and ignorantly fill the chair of this very important section of this great Association; but at least I may hope that, in Glasgow, my shortcomings do not endanger the success of our discussions, for I am confident that Glasgow men, as well as the strangers whom they so hospitably entertain, have done and will do ample justice to every subject which may be started; and I believe that Scotchmen will judge indulgently a brother Scotchman, the best part of whose life has been spent in the earnest attempt to do his duty to the many millions of our fellow-subjects in a distant dependency. 